\title{
Xenogenic bone grafting biomaterials do not interfere in the viability and proliferation of stem cells from human exfoliated deciduous teeth - an in vitro pilot study
}

Biomateriais de enxerto ósseo xenogênico não interferem na viabilidade e proliferação de célulastronco de dentes decíduos esfoliados humanos - um estudo piloto in vitro

Los biomateriales xenógenos de injertos óseos no interfieren con la viabilidad y proliferación de células madre de dientes caducifolios exfoliados humanos - un estudio piloto in vitro

Jeferson Luis de Oliveira Stroparo ORCID: https://orcid.org/0000-0003-1094-530X Universidade Positivo, Brazil E-mail: jef_stroparo@hotmail.com Suyany Gabriely Weiss ORCID: https://orcid.org/0000-0002-5778-3144 Universidade Positivo, Brazil E-mail:suyanyweiss@hotmail.com Sabrina Cunha da Fonseca ORCID: https://orcid.org/0000-0001-5280-1238

Universidade Federal do Paraná, Brazil

E-mail: sabrina.cfonseca@hotmail.com

Lisley Janowski Spisila

ORCID: https://orcid.org/0000-0002-3978-3650

Universidade Federal do Paraná, Brazil

E-mail: lisleyjspisila@gmail.com

Carla Castiglia Gonzaga

ORCID: https://orcid.org/0000-0001-6374-1605 Universidade Positivo, Brazil

E-mail: carlacgonzaga2@gmail.com

Gabriel Camargo de Oliveira ORCID: https://orcid.org/0000-0002-8720-393X Universidade Positivo, Brazil

E-mail: gabriel.oliveira538@etec.sp.gov.br

Gabriela Loewen Brotto

ORCID: https://orcid.org/0000-0002-0141-2547 Universidade Positivo, Brazil

E-mail: gabriela.1.brotto@gmail.com Alice Maria Swiech

ORCID: https://orcid.org/0000-0002-7502-6382 Universidade Positivo, Brazil

E-mail: alicemaria_swiech@hotmail.com

Eduardo Discher Vieira

ORCID: https://orcid.org/0000-0002-4311-1486 Curityba Biotech, Brasil

E-mail: eduardo.discher@outlook.com

Roberto da Rocha Leão Neto

ORCID: https://orcid.org/0000-0002-1379-7819 Universidade Positivo, Brasil E-mail: leaorep@gmail.com

Célia Regina Cavichiolo Franco ORCID: https://orcid.org/0000-0003-2525-7788 Universidade Federal do Paraná, Brazil E-mail: crcfranc@terra.com.br Moira Pedroso Leão

ORCID: https://orcid.org/0000-0003-3724-911X Curityba Biotech, Brazil

E-mail: moirapedroso@gmail.com

Tatiana Miranda Deliberador

ORCID: https://orcid.org/0000-0003-4076-4905 Instituto Latino Americano de Pesquisa e Ensino Odontológico, Brazil

E-mail: tdeliberador@gmail.com 


\begin{abstract}
Aim: In vitro evaluation of the influence of bovine xenogenic biomaterials on stem cells from human exfoliated deciduous teeth (SHEDs). The study was divided into three groups: 1) group C (control), containing only MSCs; 2) group BP, containing MSCs and Bonefill Porous®; 3) group BO, containing MSCs and Bio-Oss®. MSCs were derived from a deciduous tooth from a 7-year-old male donor. An aliquot of cells was subjected to immunophenotyping by flow cytometry. Cell viability (neutral red), cytotoxicity (MTT), and cell proliferation (crystal violet) assays were performed. All groups underwent morphological analysis by light microscopy (LM), and the biomaterial with superior performance was submitted to evaluation by scanning electron microscopy (SEM). Time points of 24,48 , and $72 \mathrm{~h}$ of culture were used. All results were evaluated with a significance level of 0.05 . Results showed that both biomaterials maintained cell viability and cytotoxicity similar to the control. The BO group showed smaller cell proliferation compared to the other groups. In LM evaluation, the BP group showed more spread and adherent cells than the BO group. In SEM, cells of the BP group showed characteristics of more active cells than those of the control. Bovine xenogenic biomaterials positively influenced SHEDs, while the BP group seemed to present higher potential with SHEDs for future application within in vivo and/or clinical studies.
\end{abstract}

Keywords: Stem cells; Biomaterials; Dental pulp.

\title{
Resumo
}

Objetivo: Avaliação in vitro da influência de biomateriais xenogênicos bovinos sobre células-tronco de dentes decíduos esfoliados humanos (SHEDs). O estudo foi dividido em três grupos: 1) grupo C (controle), contendo apenas CTMs; 2) grupo BP, contendo MSCs e Bonefill Porous ${ }^{\circledR}$; 3) grupo BO, contendo MSCs e Bio-Oss®. As CTMs foram derivadas de um dente decíduo de um doador de 7 anos de idade. Uma alíquota de células foi submetida à imunofenotipagem por citometria de fluxo. Foram realizados ensaios de viabilidade celular (vermelho neutro), citotoxicidade (MTT) e proliferação celular (cristal violeta). Todos os grupos foram submetidos à análise morfológica por microscopia de luz (ML), e o biomaterial com desempenho superior foi submetido à avaliação por microscopia eletrônica de varredura (MEV). Foram utilizados pontos temporais de 24, 48 e 72 horas de cultura. Todos os resultados foram avaliados com nível de significância de 0,05 . Os resultados mostraram que ambos os biomateriais mantiveram a viabilidade celular e citotoxicidade semelhantes ao controle. $\mathrm{O}$ grupo $\mathrm{BO}$ apresentou proliferação celular menor em comparação aos demais grupos. Na avaliação LM, o grupo BP apresentou mais células disseminadas e aderentes do que o grupo BO. No MEV, as células do grupo BP apresentaram características de células mais ativas do que as do controle. Biomateriais xenogênicos bovinos influenciaram positivamente os SHEDs, enquanto o grupo BP pareceu apresentar maior potencial com SHEDs para futura aplicação em estudos in vivo e / ou clínicos.

Palavras-chave: Células-tronco; Biomateriais; Polpa dentária.

\section{Resumen}

Objetivo: Evaluación in vitro de la influencia de los biomateriales xenógenos bovinos en células madre de dientes caducifolios exfoliados (SHEDs) humanos. El estudio se dividió en tres grupos: 1) grupo C (control), que contiene sólo MSCs; 2) grupo BP, que contiene MSCs y Bonefill Porous®; 3) Grupo BO, que contiene MSCs y Bio-Oss®. Los MSC se derivaron de un diente caducifolio de un donante de 7 años. Un conjunto celular fue sometido a inmunofennotización por citometría de flujo. Se realizaron pruebas de viabilidad celular (rojo neutro), citotoxicidad (TM) y proliferación celular (cristal violeta). Todos los grupos fueron sometidos a análisis morfológicos por microscopía ligera (ML), y el biomaterial con rendimiento superior fue sometido a evaluación mediante microscopía electrónica de barrido (SEM). Se utilizaron puntos de tiempo de 24, 48 y 72 horas de cultura. Todos los resultados fueron evaluados con un nivel de significancia de 0,05 . Los resultados mostraron que ambos biomateriales mantenían la viabilidad celular y la citotoxicidad similar al control. El grupo bo presentó una menor proliferación celular en comparación con los otros grupos. En la evaluación lm, el grupo BP presentó células más difundidas y adherentes que el grupo bo. En SEM, las células del grupo BP presentaron más características celulares activas que las del control. Los biomateriales xenógenos bovinos influyeron positivamente en los SHEDs, mientras que el grupo BP parecía presentar un mayor potencial con SHEDs para futuras aplicaciones en estudios clínicos y/o in vivo.

Palabras clave: Células madre; Biomateriales; Pulpa dental. 


\section{Introduction}

Traumatic loss of teeth or bone tissue from accidents, periodontal disease, dental caries, or other complications needs to be treated. This influences health professionals to seek reconstructive therapies such as grafts for the recovery of injured areas (Manfro et al., 2014, Sakkas et al., 2017). A bone graft, for example, needs osteogenic characteristics in order to generate new bone, including nutrients, blood supply for cell development, and a matrix that can serve as a scafolld, containing molecular signals that can be osteoinductive (Trubiani et al., 2007, Zimmermann and Moghaddam 2011).

One of the most important factors for the success of any graft is vascularization. Surgical procedures should preserve the blood supply by respecting the local anatomy, provided that, with adequate vascularization, osteointegration can occur more quickly and efficiently, in order to obtain a better-quality bone structure in a shorter time. Greater migration of osteoblasts to the region, as well as bone induction by stimulation of stem cells, increasing mineral deposition at the site, are expected (Hämmerle and Lang 2001; Amini et al., 2012).

In recent years, stem cell therapy has been tested as a new treatment option. These cells may have biological characteristics for bone regeneration, since they are both angiogenic and osteogenic (Shen et al., 2011). Mesenchymal stem cells (MSCs) have a high proliferative potential and can differentiate according to the stimulus they receive (Amini et al., 2012). Stem cells from human exfoliated deciduous teeth (SHEDs), normally discarded with exfoliated teeth, can be cryopreserved and used for research or clinical protocols. As primary teeth are usually found in very young individuals, the characteristics of these cells are promising because of their distinctive proliferative potential (Rosa et al., 2016).

Zimmermann et al. (2015) demonstrated the association of adipose stem cells (ASCs) with xenogenic biomaterials for grafting. This type of biomaterial has structural components similar to those of human bone (Amini et al., 2012), as well as a predictable rate of bone formation, allowing deposition of mature bone onto it (Hämmerle and Lang 2001, Jensen et al., 2012, Manfro et al., 2014, Zimmermann et al., 2015)

In another study, Trubiani et al. (2007) carried out tests with periodontal ligament stem cells (PDLSCs), performing osteoinduction of the stem cells sown in a bovine xenogenic biomaterial. This work demonstrates that the cells had a high affinity for three-dimensional biomaterials; cell proliferation and colonization were evident.

In vitro studies can provide important information to guide in vivo studies and clinical applications (Wolf et al., 2015). Thus, the main objective of the present work was to evaluate, in an in vitro model, the influence of bovine xenogenic biomaterials on SHEDs, in order to identify a biomaterial with greater potential for carrying cells, with the purpose of supporting further in vivo and/or clinical studies.

\section{Methodology}

\subsection{Ethical aspects}

This study was approved by the ethics committee of universidade positivo (CAAE: 13434019.7.0000.0093). The stem cells came from the disposal of an exfoliated primary tooth donated for research, from a patient treated at the paediatric dental clinic of Universidade Positivo, Curitiba, PR, Brazil. The legal guardian of the child signed a free and informed consent form. Isolation and cultivation of stem cells was performed at the cell processing center of curityba biotech, according to the protocol described by Hendijani et al. (2017).

\subsection{Study design}

This in vitro cell culture research followed similar designs, previously demonstrated like the classical work by Dominici (2006), and more recent assays as demonstrated by Santos et al. (2021). MTT assay followed Mosmann (1983), Lu 
et al. (2012) and Gomez et al. (2017); cell proliferation followed Chiba et al. (1998); and neutral red assay followed Chiba et al. (1998), Repetto et al. (2008) and Gomez et al. (2017). Tests were carried out in 24-well plates in duplicate triplicate. After cells reached confluence $(70 \%)$, they were washed with PBS at $37{ }^{\circ} \mathrm{C}$, chemically de-activated under trypsin-EDTA, and counted in a Neubauer chamber. $2 \times 10^{4}$ cells were plated per well, according to group:1) C group (Control), containing only MSCs;2) BP group (Bonefill Porous®, average granulation 0.60-1.50mm, Bionnovation Biomedical, Bauru, Brazil), containing MSCs and $3 \mathrm{mg}$ of biomaterial inside a3- $\mu \mathrm{m}$ porosity insert (EasyStrainer, GreinerBio-One, Kremsmünster, Austria); 3) BO group (Bios-Oss®, medium granulation 0.25-1.0mm, Geistlich Pharma, Switzerland),containing MSCs and 3 $\mathrm{mg}$ of biomaterial inside a $3-\mu \mathrm{m}$ porosity insert. All groups were maintained for 24,48 , and $72 \mathrm{~h}$, and then tested.

\subsection{Isolation and cell culture}

After obtaining the exfoliated tooth, remnants of the crown and pulp were placed in a Falcon tube (BD Biosciences, Franklin Lakes, NJ, USA) containing $15 \mathrm{~mL}$ of transport medium (1\% antifungal at $250 \mu \mathrm{g} / \mathrm{kg}$ [amphotericin B], $1 \%$ antibiotic [penicillin $100 \mathrm{IU} / \mathrm{mL}$ and streptomycin $100 \mathrm{mg} / \mathrm{mL}$ - Gibco, Waltham, MA, USA]), and culture medium (DMEM, lowglucose with L-glutamine and solid pyruvate - Gibco, Waltham, MA, USA). The tube was then immediately taken to the laboratory for sample processing. Inside a type II biological safety cabinet (Telstar Bio II Advance, FACScalibur, BD, Franklin Lakes, USA), installed in an ISO 7 clean room, the tissue was fractionated to isolate mesenchymal stem cells (MSCs) using the explant technique. It is necessary to fragment the tissue into several pieces of approximately $1 \mathrm{~mm}^{2}$, and to place these fragments at the bottom of a $25-\mathrm{cm} 3$ bottle (BD Biosciences), maintaining an approximate distance of $3 \mathrm{~mm}$ between them. Subsequently, the material was placed in an incubator at $37{ }^{\circ} \mathrm{C}$, with $5 \% \mathrm{CO}_{2}$ and $95 \%$ humidified, saturated air (Panasonic, Japan) until the explants adhered to the bottom of the bottle. After this step, $5 \mathrm{~mL}$ of supplemented standard culture medium was added to the bottle, and additional care was taken so that the fragments did not detach from the bottom. Explants were placed back into the incubator for $48 \mathrm{~h}$ at $37{ }^{\circ} \mathrm{C}\left(+/-2{ }^{\circ} \mathrm{C}\right), 5 \% \mathrm{CO}_{2}, 95 \%$ humidified and saturated air, with the change of medium afterwards. The cells were checked under an inverted microscope (AE 31 Trinuclear, MOTIC, China) until they reached $70 \%$ confluence ( 3 rd passage, $1.5 \times 10^{6}$ cells).

\subsection{Flow cytometry}

Third passage cells underwent flow cytometry (FACScalibur, BD, Franklin Lakes, NJ, USA) to analyze surface markers (Laboratory of the Nucleus of Cellular Technology of the Pontifical Catholic University of Paraná, Curitiba, Brazil). The established criteria considered positive results above $70 \%$ and negative results below $10 \%$. To assess viability, the apoptosis and necrosis cell detection kit (APC Annexin V Apoptosis Detection Kit with 7-AAD, BioLegend, San Diego, CA, USA) was also used. For immunophenotyping, CD105, CD73, and CD90 markers were considered positive, and CD45, CD34, CD14 or CD11b, CD79a or CD19, and HLA-DR were considered negative, according to the Dominici (2006) protocol. $1 \times$ $10^{5}$ cells were used per cytometry tube, and each sample was passed through the cytometer once. Specific primary antibodies were also used: anti-human mouse CD105 (Invitrogen, Carlsbad, CA, USA), anti-human mouse CD73, CD90, CD45, CD34, CD11b, CD19, and HLA-DR (ABD Serotec, Raleigh, NC, USA). The corresponding isotype antibody was used as a negative control, and a secondary goat anti-mouse IgG antibody (H/L - FITC, ABDSerotec) was used. The data obtained were analyzed using FlowJo software (TreeStar, Ashland, OR, USA).

\subsection{Cell cytotoxicity (MTT)}

Approximately $2 \times 10^{4}$ cells/well were plated in a 24-well plate in triplicate, with a volume of $200 \mu \mathrm{L} /$ well. After $24 \mathrm{~h}$, the supernatant was replaced, and the cells were incubated with biomaterials placed inside a transwell (ThinCert, Greiner-Bio 
One International, Americana, Brazil) for 24, 48, and $72 \mathrm{~h}$. After the treatment times had elapsed, the medium was removed, and $200 \mu \mathrm{L}$ of 3,4,5-dimethyl-2-thiazolyl-2,5-diphenyl-2H-tetrazolium bromide solution (MTT) diluted in PBS was added (0.5 $\mathrm{mg} / \mathrm{mL}$ ). The plates were protected from light, and after $3 \mathrm{~h}$ of incubation at $37{ }^{\circ} \mathrm{C}$ and $5 \% \mathrm{CO}_{2}$ the supernatant was removed and the cells were resuspended in $200 \mu \mathrm{L}$ dimethyl sulfoxide (DMSO). Absorbance was measured at a wavelength of $545 \mathrm{~nm}$ using a microplate reader (Epoch, Biosystem Biotek, Winooski, VT, USA). The results were analyzed using GraphPad Prism software (GraphPad Software, Inc., San Diego, CA, USA)(4, 9).

\subsection{Cell proliferation (crystal violet) and cell viability (neutral red)}

Approximately $2 \times 10^{4}$ cells/well were plated in a 24 -well plate, in $200 \mu \mathrm{L} / w e l l$, in triplicate. After $24 \mathrm{~h}$, the supernatant was replaced and the cells were incubated with the biomaterials placed inside a transwell (ThinCert, Greiner-Bio One International, Americana, Brazil) for 24, 48, and $72 \mathrm{~h}$.

For cell proliferation assessment, all of the supernatant solution was removed from the plates, which were washed with PBS and fixed with $50 \mu \mathrm{L}$ of methanol per well for 3 min. Methanol was then removed, and $100 \mu \mathrm{L}$ of $0.2 \%$ crystal violet $5 \%$ ethanol was added and incubated for $10 \mathrm{~min}$. Wells were then washed in PBS six times to remove any residual dye. Then, $200 \mu \mathrm{L}$ of $0.1 \mathrm{M}$ sodium citrate in $50 \%$ ethanol was added. Absorbance was read at $550 \mathrm{~nm}$ on a microplate reader (Epoch, Biosystem Biotek).

Likewise, to evaluate cell viability, after the treatment times had elapsed, the medium was removed, and $200 \mu \mathrm{L}$ of neutral red solution diluted in PBS $(550 \mu \mathrm{g} / \mathrm{mL})$ was added and incubated for $2 \mathrm{~h}$ at $37{ }^{\circ} \mathrm{C}$ with $5 \% \mathrm{CO}_{2}$. All the supernatant was removed, wells were then washed in PBS, $100 \mu \mathrm{L}$ of the extraction solution (ethanol 50\%, ultrapure water and glacial acetic acid; 50:49:1/vol.) was added, and plates were homogenized. Absorbance was read at $550 \mathrm{~nm}$ (Epoch, Biosystem Biotek).

Results were analyzed using GraphPad Prism software (GraphPad Software, Inc.).

\subsection{Light microscopy (LM) and scanning electron microscopy (SEM)}

Before samples were inserted into the microplate reader for the proliferation assay, an inverted microscope (AE 31 Trinuclear, MOTIC, China) was used for image capture and basic morphological evaluation of the cells (20× magnification). According to the prior results, one of the testing groups and the control group underwent a SEM protocol (Santos et al., 2021) . For evaluation of the ultrastructure $(\mathrm{SEM}), 2 \times 10^{4}$ cells were plated in 24-well plates containing 13-mm diameter circular coverslips at the bottom. Afterwards, the cells were fixed in Karnovsky's solution (2\% glutaraldehyde, $4 \%$ paraformaldehyde, $1 \mathrm{mM} \mathrm{CaCl}_{2}$ in $0.1 \mathrm{M}$ cacodylate buffer) for $1 \mathrm{~h}$. After fixation, the cells were washed with $0.1 \mathrm{M}$ sodium cacodylate buffer, with $\mathrm{pH} 7.4$, and dehydrated in ethanol (in a sequence of 30, 50, 70, 90\%, and twice in $100 \%$ ) for $10 \mathrm{~min}$ at each concentration. After dehydration, the coverslips were subjected to critical drying (Critical Point Dryer 030, Bal-Tec, Balzers, Liechtenstein) and metallization with gold (SCD 030, Bal-Tec, Balzers, Liechtenstein), then analyzed using a scanning electron microscope (TESCAN VEGA 3 LMU, Brno, Czech Republic). Afterwards, the images obtained were evaluated using the ImageJ program (NIH, USA) to assess the percentage of cells per unit of area. These analyses were performed at the Center for Electronic Microscopy at the Federal University of Paraná, Brazil.

\subsection{Statistical analysis}

To assess the normality of the data, the Shapiro-Wilk test was used. Data on the different cytotoxicity, proliferation, and cell viability assays were statistically analyzed by two-way ANOVA and Tukey's test. All analyses were performed with a significance level of 0.05, using the Statistical Package for Social Science Software (SPSS 24.0). 


\section{Results}

\subsection{Flow cytometry}

The results of using the cell detection kit for apoptosis and necrosis were as follows: cells in apoptosis (0.43\%); cells in necrosis (5.27\%); and cell viability (94.3\%). Surface markers confirmed the phenotype of mesenchymal stem cells, positive for CD105 (88.9\%); CD73 (93.5\%); and CD90 (97.9\%). Negative for: CD45 (1.03\%), CD34 (0.78\%); CD14 (2.17\%); CD19 $(2.34 \%)$; and HLA-DR $(0.74 \%)$.

\subsection{Cytotoxicity, cell viability, and proliferation assays}

For the cytotoxicity assay, the results indicated statistically significant differences in the biomaterial factor ( $p=$ 0.004) Also, significant diferences were observed regarding time $(p<0.001)$. The double interaction was also statistically significant $(p=0.038)$.

Thus, according to Table 1 , in $48 \mathrm{~h}$, the BO group showed higher cytotoxicity (lower value $=0,2023 \pm 0,0202$ ) than the BP and C group $(0,2457 \pm 0,465)$. At $72 \mathrm{~h}$, both biomaterial groups demonstrated similar results of cytotoxicity $(\mathrm{BP}=$ $0,2993 \pm 0,0249$ and $\mathrm{BO}=0,3238 \pm 0,0283)$.

Table 1. Means and standard deviations for cytotoxicity values (MTT assay) for different groups.

\begin{tabular}{c|c|c|c}
\hline \multirow{2}{*}{ Biomaterial } & \multicolumn{3}{|c}{ Period } \\
\cline { 2 - 4 } & $\mathbf{2 4 h}$ & $\mathbf{4 8 h}$ & $\mathbf{7 2 h}$ \\
\hline $\mathbf{C}$ & $0,2482 \pm 0,0328 \mathrm{Ba}$ & $0,2398 \pm 0,0142 \mathrm{Bab}$ & $0,3545 \pm 0,0317 \mathrm{Aa}$ \\
\hline BP & $0,2337 \pm 0,0221 \mathrm{Ba}$ & $0,2457 \pm 0,465 \mathrm{Ba}$ & $0,2993 \pm 0,0249 \mathrm{Ab}$ \\
\hline BO & $0,2182 \pm 0,0143 \mathrm{Ba}$ & $0,2023 \pm 0,0202 \mathrm{Bb}$ & $0,3238 \pm 0,0283 \mathrm{Aab}$ \\
\hline
\end{tabular}

In lines, means followed by the same capital letters are statistically similar ( $>$ > 0.05). In columns, means followed by the same lower case letters are statistically similar $(\mathrm{p}>0.05) . \mathrm{C}=$ control group. $\mathrm{BP}=$ Bone Fill Porous ${ }^{\circledR}$ biomaterial group. $\mathrm{BO}=$ Bio-Oss ${ }^{\circledR}$ biomaterial group. Source: Authors.

The results (means) for the neutral red test (viability) indicated statistically significant differences for the biomaterial factor $(p=0.010)$ and time $(p<0.001)$. The double interaction was also statistically significant $(p=0.029)$. At $24 \mathrm{~h}$, the BP group presented lower viability $(1,2243 \pm 0,1255)$ when compared to group BO $(1,4582 \pm 0,1631)$. At $48 \mathrm{~h}$, the group BO demonstrated a lower viability when compared do group C $(1,1158 \pm 0,1254$ and 1,3623 $\pm 0,0517$, respectively). Nevertheless, at the final $72 \mathrm{~h}$, all groups showed the same viability.

Table 2. Means and standard deviations for cell viability values (neutral red assay) for different groups.

\begin{tabular}{l|c|c|c}
\hline \multirow{2}{*}{ Biomaterial } & \multicolumn{3}{|c}{ Period } \\
\cline { 2 - 4 } & $\mathbf{2 4 h}$ & $\mathbf{4 8 h}$ & $\mathbf{7 2 h}$ \\
\hline C & $1,4922 \pm 0,2504 \mathrm{Aba}$ & $1,3623 \pm 0,0517 \mathrm{Ba}$ & $1,6602 \pm 0,0702 \mathrm{Aa}$ \\
\hline BP & $1,2243 \pm 0,1255 \mathrm{Bb}$ & $1,2433 \pm 0,0487 \mathrm{Bab}$ & $1,6307 \pm 0,1237 \mathrm{Aa}$ \\
\hline BO & $1,4582 \pm 0,1631 \mathrm{Aa}$ & $1,1158 \pm 0,1254 \mathrm{Bb}$ & $1,5368 \pm 0,2305 \mathrm{Aa}$ \\
\hline
\end{tabular}

In lines, means followed by the same capital letters are statistically similar ( $p>0.05$ ). In columns, means followed by the same lower case letters are statistically similar $(\mathrm{p}>0.05) . \mathrm{C}=$ control group. $\mathrm{BP}=$ Bone Fill Porous ${ }^{\circledR}$ biomaterial group. $\mathrm{BO}=$ Bio-Oss ${ }^{\circledR}$ biomaterial group. Source: Authors. 
For the cell proliferation assay, results indicated statistically significant differences for the biomaterial factor ( $p=$ $0.007)$ and time $(p<0.001)$. The double interaction was not statistically significant $(p=0.091)$. Thus, as shown in Table 3 , the highest level of proliferation can be seen at $72 \mathrm{~h}$ within the groups altogether $(0,5333 \pm 0,1034)$. However, when separating the groups, the group BO demonstrated the lowest proliferation levels $(0,2863 \pm 0,1753)$.

Table 3. Means and standard deviations for the proliferation values (crystal violet assay) for different groups.

\begin{tabular}{l|c|c|c|c}
\hline \multirow{2}{*}{ Biomaterial } & \multicolumn{4}{|c}{ Period } \\
\cline { 2 - 5 } & $\mathbf{2 4 h}$ & $\mathbf{4 8 h}$ & $\mathbf{7 2 h}$ & Total \\
\hline $\mathrm{C}$ & $0,2273 \pm 0,0306$ & $0,2447 \pm 0,0344$ & $0,6005 \pm 0,0572$ & $\mathbf{0 , 3 5 7 5} \pm \mathbf{0 , 1 8 1 4}$ a \\
\hline BP & $0,1962 \pm 0,0109$ & $0,2655 \pm 0,0448$ & $0,5043 \pm 0,0684$ & $\mathbf{0 , 3 2 2 0} \pm \mathbf{0 , 1 4 3 0}$ a \\
\hline BO & $0,2032 \pm 0,0439$ & $0,1608 \pm 0,0536$ & $0,4950 \pm 0,1422$ & $\mathbf{0 , 2 8 6 3} \pm \mathbf{0 , 1 7 5 3 ~ b}$ \\
\hline Total & $\mathbf{0 , 2 0 8 9} \pm \mathbf{0 , 0 3 2 6} \mathbf{B}$ & $\mathbf{0 , 2 2 3 7} \pm \mathbf{0 , 0 6 2 8} \mathbf{B}$ & $\mathbf{0 , 5 3 3 3} \pm \mathbf{0 , 1 0 3 4} \mathbf{A}$ & \\
\hline
\end{tabular}

In lines, means followed by the same capital letters are statistically similar ( $p>0.05$ ). In columns, means followed by the same lower case letters are statistically similar $(\mathrm{p}>0.05) . \mathrm{C}=$ control group. $\mathrm{BP}=$ Bone Fill Porous $₫$ biomaterial group. $\mathrm{BO}=$ Bio-Oss $®$ biomaterial group. Source: Authors.

\subsection{Light microscopy (LM) morphological analysis of control cells and cells exposed to biomaterials BP and BO cells}

LM analyses showed that cells in group C were well maintained in cell culture in the presence of medium after $24 \mathrm{~h}$ (Figure 1A), 48h (Figure 1B), and 72h (Figure 1C), adhered and spread to the substrate, with different morphological patterns. These were cells that remained arranged side by side and showed contact inhibition. Subconfluent cells are evident in $1 \mathrm{~A}$ and 1B. As shown in $1 \mathrm{C}$, after $72 \mathrm{~h}$, a greater dynamics of cell proliferation was observed, with a higher number of cells but still in subconfluence. These cells also emitted characteristic projections of the cell body, producing cells with different morphologies. Figures $1 \mathrm{~A}$ and $1 \mathrm{~B}$ show smaller, rounded cells, characteristic of dead or stressed cells. This indicated a characteristic morphological pattern for the control cell line.

Figures 1D. 1E and 1F show cells exposed to the BP biomaterial. These cells showed similar characteristics to those in group $\mathrm{C}$, regarding the morphological pattern. The cells remain adhered and spread to the substrate. After treatment, they were not stacked, and kept side by side with contact inhibition. Interestingly, these cells have a clearer shape compared to group C (1A-1C), especially at 48 and $72 \mathrm{~h}$. It can be observed that these cells are more elongated, with a clear filiform morphology. It is evident that after exposure to the biomaterial, at $48 \mathrm{~h}(1 \mathrm{E})$, there were a greater number of cells when compared with group $\mathrm{C}$ after the same time of exposure (1B). This result was enhanced in group BP at $72 \mathrm{~h}(1 \mathrm{~F})$, compared to group C (1C). At $48 \mathrm{~h}(1 \mathrm{E})$, BP cells had almost reached cell confluence, and by $72 \mathrm{~h}(1 \mathrm{~F})$ confluence was evident. The round morphology was seen only at $24 \mathrm{~h}$ (1D), and at 48 and $72 \mathrm{~h}$ there were no round cells (1E and $1 \mathrm{~F}$, respectively).

Within the group BO (Figures $1 \mathrm{G}$ to $1 \mathrm{I})$, after $24 \mathrm{~h}(1 \mathrm{G}), 48 \mathrm{~h}(1 \mathrm{H})$, and $72 \mathrm{~h}(1 \mathrm{I})$, the treated cells presented the lowest number of cells at all times when compared to the group C, and in particular to the group BP. It is noteworthy that at 24 h (1G), when compared to C (1A), there is a change in the morphological pattern of these cells. The cell body presented bulky roundness morphology; cells are smaller and tapered than elongated, as they become more round and bulky. This can suggest that they are losing their ability to spread over the substrate and losing cell adhesion, which is normally known as ANOIKIS, as can be observed in $1 \mathrm{G}(24 \mathrm{~h}), 1 \mathrm{H}(48 \mathrm{~h})$, and $1 \mathrm{I}(72 \mathrm{~h})$. A smaller number of cells was observed at all analyzed times for this group than for the other two groups. In this group (BO), cells did not reach confluence at $72 \mathrm{~h}$ (1I). 
Figure 1. Morphological analysis by light microscopy (LM) of stem cells from human exfoliated deciduous teeth, in groups $C$ (control), BP (Bone Fill Porous®), and BO (Bio-Oss $\left.{ }^{\circledR}\right)$ for 24, 48, and 72 hours.
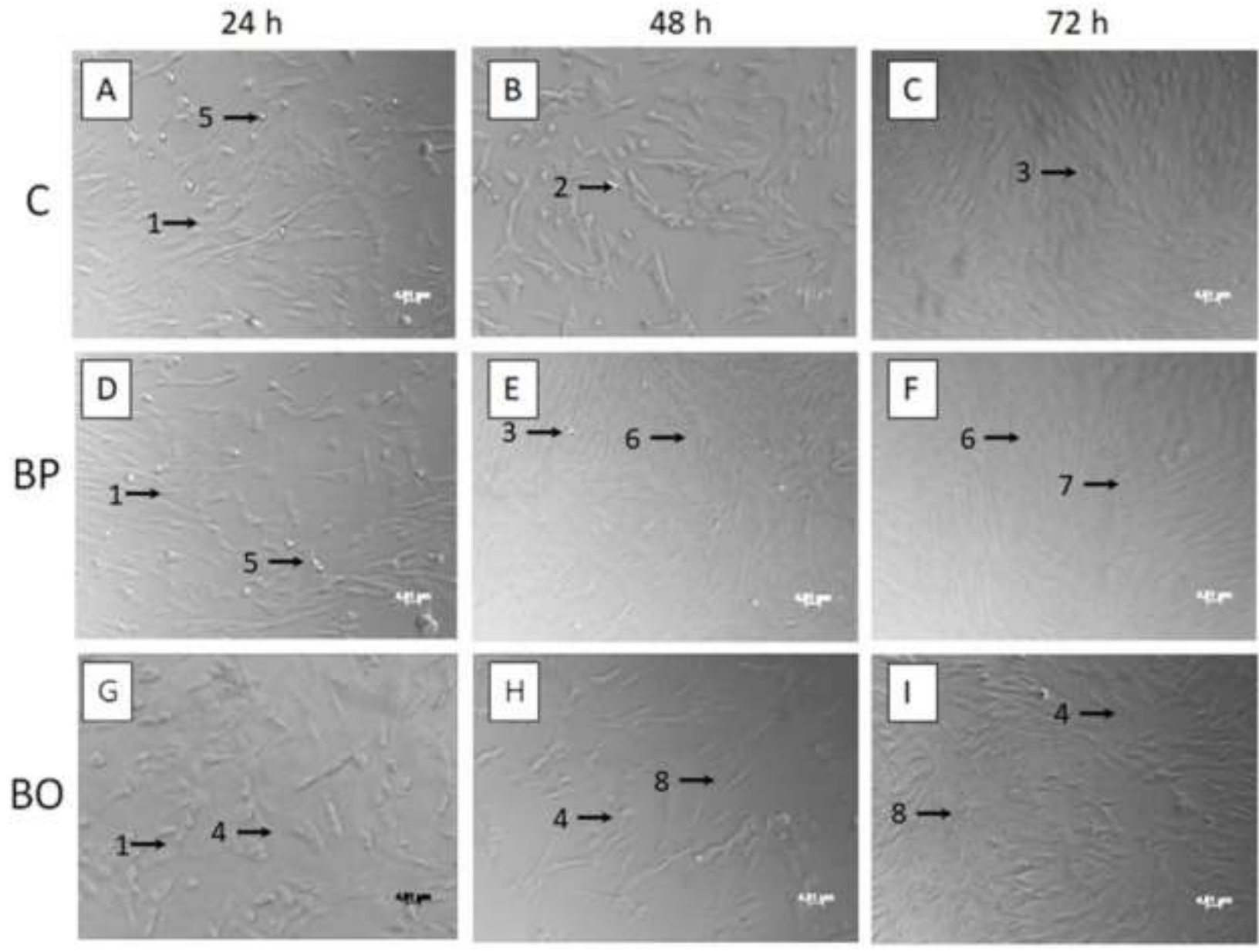

Panels A-C show C cells kept in DMEM. Panels D-F show cells exposed to BP. Panels G-I show cells exposed to BO. All images are at 20× magnification. Arrows: $1=$ cells adhered and spread to the substrate; $2=$ cells with different morphological patterns; $3=$ inhibition contact; $4=$ cells in subconfluence; $5=$ rounded cells; $6=$ more elongated cells, spread and adhered to the substrate; $7=$ cells in confluence; $8=$ separated and subconfluence cell. Source: Authors.

\subsection{Morphological and ultrastructural analysis by scanning electron microscopy (SEM) of C and BP cells}

SEM analyses (Figure 2) showed that C cells (Figures $2 \mathrm{~A}$ to 2D), after $72 \mathrm{~h}$, were adhered and spread to the substrate, with different morphological patterns and contact inhibition characteristics. Cells did not pile up, and were instead kept side by side. It is also possible to observe cells in evident subconfluence, with projections of the cell body and different morphologies, such as filopodia, all along the cell body, and structures of cellular perception. It is possible to see, over the culture (Figures $2 \mathrm{~A}$ and $2 \mathrm{~B}$ ), rounded cells of smaller size, characteristic of either dead cells or cells in the process of division. There is vesicular material across the cell body, similar to that involved in cell secretion processes, as well as particulate material.

Figures $2 \mathrm{E}$ to $2 \mathrm{H}$ are from group $\mathrm{BP}$ at $72 \mathrm{~h}$, showing cells with some similar characteristics to group C, such as cells remaining adhered and spread to the substrate, staying side by side. It can also be seen that BP cells (Figures $2 \mathrm{E}, 2 \mathrm{~F}$, and $2 \mathrm{G}$ ) were larger than $\mathrm{C}$ cells (Figures 2A, 2B, and 2C). They stretched the cell body further, and began to emit few and sparse membrane and filopodia-like projections. Particulate material of different sizes across the cell culture as well as abundant vesicular processes similar to those seen in cell secretion processes, were observed. 
Figure 2. SEM analysis stem cells from human exfoliated deciduous teeth, in groups C (control) and BP (Bone Fill Porous $\left.{ }^{\circledR}\right)$, at 72 hours.
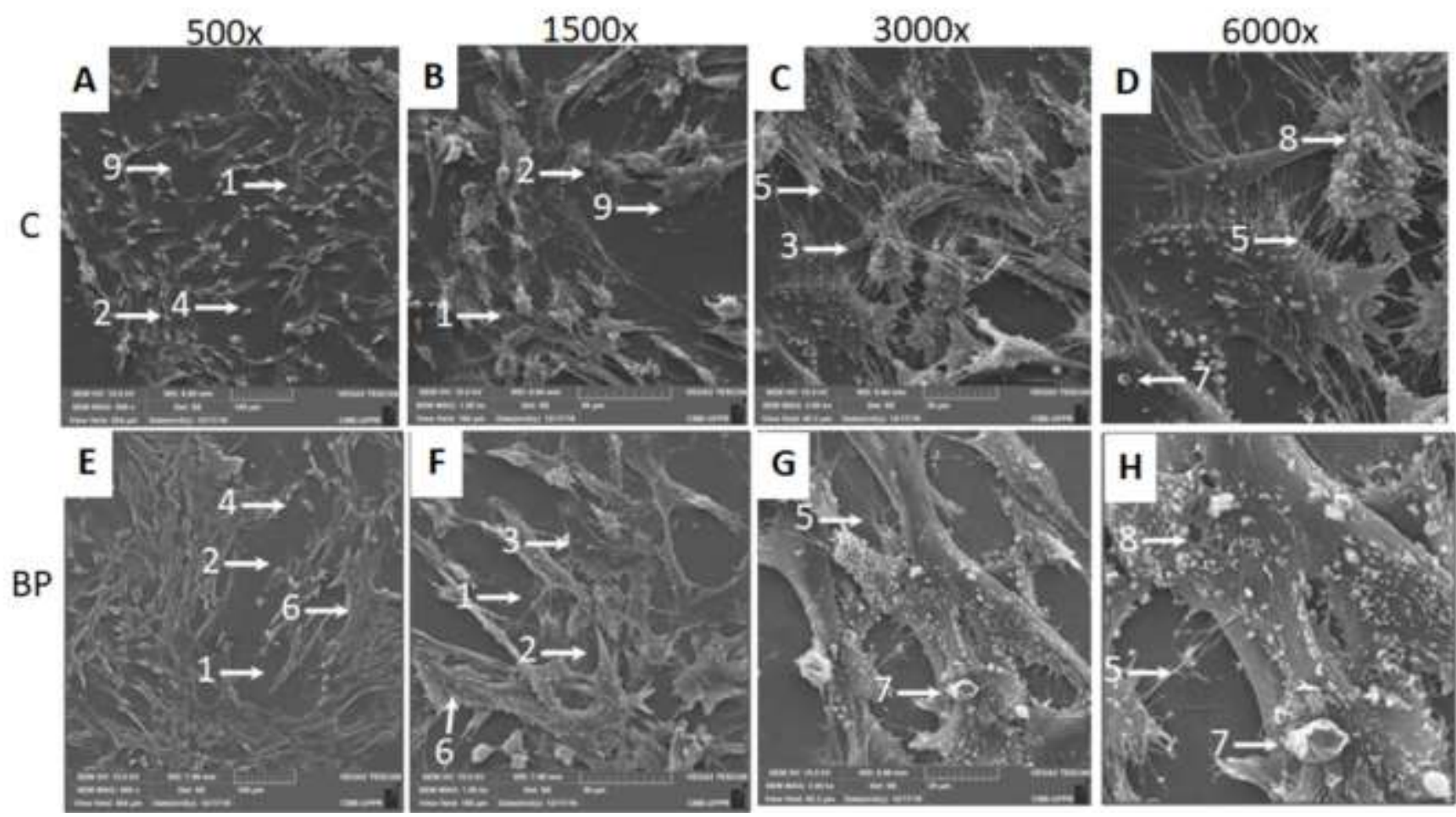

Panels A-D show group C cells. Panels E-H show BP cells. Panels A and E are at 500× magnification, and panels B and F are at 1500× magnification. Panels $\mathrm{C}$ and $\mathrm{G}$ are at $3000 \times$ magnification. Panels D, E, and $\mathrm{H}$ are at $6000 \times$ magnification. Arrows: $1=$ cells adhered and spread to the substrate; $2=$ cells with different morphological patterns; $3=$ inhibition contact; $4=$ cells in subconfluence; $5=$ cellular projections in the form of filopodia; $6=$ larger cells with more elongated morphology; 7 = particulate material of different sizes over cell culture; $8=$ cells with abundant vesicular processes, similar to cell secretion processes; $9=$ fewer cells, smaller cells, less spread, with more rounded cells. Source: Authors.

\section{Discussion}

Mesenchymal stem cells may have great osteogenic potential, especially when larger bone reconstructions are required for rehabilitation with dental implants. With the increase in availability of xenogenic biomaterials for grafting purposes, and the potential for clinical application of stem cells to improve the performance of grafts, it is important to evaluate the influence of biomaterials on these cells before in vivo and/or clinical human studies can be performed (Wolf et al., 2015, Zimmermann et al., 2015, Zeitlin, 2020).

One of the advantages of SHEDs is that they come from tissues that are normally discarded. These young cells show that their proliferation rate is higher than that of bone marrow-derived stem cells or DPSCs, which are also considered valuable sources of stem cells (Rafatjou et al., 2018).

In the present work, particulate biomaterials were used inside transwells in order to avoid direct mixing with the cells, conventionally cultivated at the bottom of the wells. This facilitated their recovery for evaluation, while allowing exposure to the biomaterial. This setup differs from cell migration tests, in which the biomaterial is at the bottom of the well and the cells are in the transwell (Wang et al., 2018, Dahake et al., 2020, Kunwong et al., 2021). The methodology used in this study allowed the cell culture in the presence of biomaterials, and should continue in longer periods (further work) until cell differentiation is clearly reached.

In order to decrease the chance of bias in cytotoxicity and cell proliferation assessments, these basic culture tests are important to characterize the basic design study and to serve as guidance for further studies (Chiba et al., 1998). 
During the MTT test, at $48 \mathrm{~h}$, the BO group presented higher cytotoxicity than the others, although both biomaterials presented the same cytotoxicity at $72 \mathrm{~h}$. Vasilyev et al. (2018) also shows higher cytotoxicity in the presence of the biomaterial BO.

Regarding viability with neutral red, according to a methodology adapted from previous studies (Repetto et al., 2008; Gomez et al., 2017), we noticed that the BP group began the test with the lowest values, and equaled the results of the other groups within $72 \mathrm{~h}$, when all groups presented the same results. The work of Rasch et al. (2019) used the 24 and $72 \mathrm{~h}$ periods too, however, the stem cells were placed directly on the surface of the biomaterial, resulting in a lower viability rate with the association of BO (Bio-Oss®). However, no information about cell migration into the body of the biomaterial was considered.

Cell proliferation results provided significant data. The $72 \mathrm{~h}$ results were more favorable for the $\mathrm{C}$ and $\mathrm{BP}$ groups. In the work of Hosseini et al. (2019), the Bio-Oss® coated with polycaprolactone provided a surface that stimulated cell proliferation, in contrast to the current study, in which the cellular influence in the presence of pure Bio-Oss® presented the worst performance, or lowest overall proliferation rate.

Regarding morphological aspects seen by LM, the appearance of the BP group cells was different from both the C and $\mathrm{BO}$ groups. A greater proliferation was observed in BP than in BO, besides the noticeable displacement process (ANOIKIS) observed in the BO group, represented by the loss of cell ability to adhere and spread. In the BP group, cells were more adhered and spread, while almost reaching confluence at $48 \mathrm{~h}$ and definitely reaching confluence at $72 \mathrm{~h}$, differently than the groups $\mathrm{C}$ and $\mathrm{BO}$. The BO group presented more round cells with more space among them, a typical characteristic of cell suffering. In the work of Hosseini et al. (2019), the morphology of the stem cells (from adipose tissue, bone marrow, and umbilical cord) is different from the SHEDs used in this work. Also, the biomaterial used (Bio-Oss®) was coated with a polymer, and their results also demonstrate an increase in cell proliferation.

Thus, due to those morphology characteristics and cell proliferation observed by LM, further SEM analysis was performed at $72 \mathrm{~h}$. Parameswaran and Verma (2011) describe osteogenic nodular vesicular formations on the surface of bone marrow stem cells, similar to the findings of the current study, in which BP cells presented many nodular secretions. The larger, more elongated cells, with few and sparse membrane projections, in addition to spreading and profuse interaction with the substrate, indicated that SHEDs on this BP group maintained high cell viability. Therefore, the presence of the biomaterial did not exert a cytotoxic effect, which can likely be suggested to be used in advanced cell therapy. These results with this xenogenic biomaterial (BP) can corroborate for its further use in vivo and clinical studies, particularly because of its commercial availability and relatively low costs.

Nevertheless, and promisingly, in the present study design, the cells in the group BP showed better proliferation results, larger and more elongated cells, spread and in close contact with the substrate.

\section{Conclusion}

It was possible to conclude within the scope of the present work, that the xenogenic biomaterials herein evaluated influenced SHEDs in terms of cell viability, cytotoxicity, and proliferation, as well as their morphological and ultrastructural characteristics. The cells remained viable without cytotoxic action and maintained their proliferative capacity. In this particular study design, the BP biomaterial presented higher potential SHED association for future in vivo and/or clinical studies.

For in vivo study designs, the use of critical defects in rat's calvaria can represent the next research step, which can elucidate more biological and physiological responses. Other (larger) animal models can also be used, such as sheep, in order to clarify questions regarding scaling and handling in surgical procedures. With more information and filling of legal and ethical concerns, initial tests of safety and efficacy can be designed for clinical application in humans. 


\section{Acknowledgments}

The authors declare no conflict of interests in this study. Also, they would like to thank the synergistic activities displayed by all laboratories and researchers involved in this work.

\section{References}

Amini A. R., Laurencin, C. T., \& Nukavarapu, S. P. (2012).Bone tissue engineering: recent advances and challenges. Crit Rev Biomed Eng. 40(5):363-408. doi:10.1615/critrevbiomedeng.v40.i5.10.

Chiba, K., Kawakami K., \& Tohyama, K. (1998). Simultaneous evaluation of cell viability by neutral red, MTT and crystal violet staining assays of the same cells. Toxicol In Vitro. 12(3):251-258. doi:10.1016/s0887-2333(97)00107-0.

Dahake, P. T., Panpaliya, N. P., Kale, Y. J., Dadpe, M. V., Kendre, S. B., \& Bogar, C. (2020). Response of stem cells from human exfoliated deciduous teeth (SHED) to three bioinductive materials - An in vitro experimental study. Saudi Dent J. 2020 Jan;32(1):43-51. doi: 10.1016/j.sdentj..05.005.

Dominici, M., Le Blanc, K., \& Mueller, I., et al. (2006). Minimal criteria for defining multipotent mesenchymal stromal cells. The International Society for CellularTherapy position statement. Cytotherapy;8(4):315-317. doi:10.1080/14653240600855905.

Gomez, P. M., Fourcade, L., Mateescu, M. A., \&. Paquin, J. (2017). Neutral Red versus MTT assay of cell viability in the presence of copper compounds. Anal Biochem. 535:43-46. doi:10.1016/j.ab.2017.07.027.

Hämmerle, C. H., Lang, N. P. (2001). Single stage surgery combining transmucosal implant placement with guided bone regeneration and bioresorbable materials. Clin Oral Implants Res. 12(1):9-18. doi:10.1034/j.1600-0501.2001.012001009.x.

Hendijani, F. (2017). Explant culture: An advantageous method for isolation of mesenchymal stem cells from human tissues. Cell Prolif:;50(2):e12334. doi:10.1111/cpr.12334.

Hosseini, F. S., Soleimanifar, F., \& Ardeshirylajimi, A., et al. (2019). In vitro osteogenic differentiation of stem cells with different sources on composite scaffold containing natural bioceramic and polycaprolactone. Artif Cells NanomedBiotechnol. 47(1):300-307. doi:10.1080/21691401.2018.1553785.

Jensen, T., Schou, S., Stavropoulos, A., Terheyden, H., Holmstrup, P. (2012). Maxillary sinus floor augmentation with Bio-Oss or Bio-Oss mixed with autogenous bone as graft: a systematic review. Clin Oral Implants Res. 23(3):263-273. doi:10.1111/j.1600-0501.2011.02168.x.

Kunwong, N., Tangjit, N., Rattanapinyopituk, K., Dechkunakorn, S., Anuwongnukroh, N., Arayapisit, T., \& Sritanaudomchai. H. (2021). Optimization of poly (lactic-co-glycolic acid)-bioactive glass composite scaffold for bone tissue engineering using stem cells from human exfoliated deciduous teeth. Arch Oral Biol. 123:105041. doi: 10.1016/j.archoralbio.2021.105041.

Lü, L., Zhang, L., Wai, M. S., Yew, D. T., \& Xu, J. (2012). Exocytosis of MTT formazan could exacerbate cell injury. Toxicol In Vitro. 26(4):636-644. doi:10.1016/j.tiv.2012.02.006.

Manfro, R., Fonseca, F. S., Bortoluzzi, M. C., \& Sendyk, W. R. (2014). Comparative, Histological and Histomorphometric Analysis of Three Anorganic Bovine Xenogenous Bone Substitutes: Bio-Oss, Bone-Fill and Gen-Ox Anorganic. J Maxillofac Oral Surg. 13(4):464-470. doi:10.1007/s12663-013-0554-z.

Mosmann, T.(1983). Rapid colorimetric assay for cellular growth and survival: application to proliferation and cytotoxicity assays. J Immunol Methods. $16 ; 65(1-2): 55-63$.

Parameswaran, S., \& Verma, R. S. (2011). Scanning electron microscopy preparation protocol for differentiated stem cells. Anal Biochem. 416(2):186-190. doi:10.1016/j.ab.2011.05.032.

Rafatjou, R., Amiri, I., \& Janeshin, A. (2018). Effect of Calcium-enriched Mixture (CEM) cement on increasing mineralization in stem cells from the dental pulps of human exfoliated deciduous teeth. J Dent Res DentClinDent Prospects. 12(4):233-237. doi:10.15171/jpid.2018.036.

Rasch, A., Naujokat, H., Wang, F., Seekamp, A., Fuchs, S., \& Klüter, T. (2019). Evaluation of bone allograft processing methods: Impact on decellularization efficacy, biocompatibility and mesenchymal stem cell functionality. PLoS One. 14(6):e0218404. Published 2019 Jun 20. doi:10.1371/journal.pone.0218404.

Repetto G, del Peso A, Zurita J. L. (2008). Neutral red uptake assay for the estimation of cell viability/cytotoxicity. Nat Protoc. 3(7):1125-1131. doi:10.1038/nprot.2008.75.

Rosa, V., Dubey, N, Islam, I., Min, K. S., \& Nör, J. E. (2016). Pluripotency of Stem Cells from Human Exfoliated Deciduous Teeth for Tissue Engineering. Stem Cells Int.2016:5957806. doi:10.1155/2016/5957806.

Sakkas, A., Wilde, F., Heufelder, M., Winter, K., \& Schramm, A. (2017). Autogenous bone grafts in oral implantology-is it still a "gold standard"? A consecutive review of 279 patients with 456 clinical procedures. Int J Implant Dent. 3(1):23. doi:10.1186/s40729-017-0084-4.

Santos, V. L. P; Franco, C. R. C.; Wagner, R.; Silva, C. D.; Franco, C. C.; Wagner, R.; Silva, C. D.; Santos, G. F.; Cunha, R. S.; Stinghen, A. E. M.; Monteiro, L. M.; Bussade, J. E.; Budel, J. M.; \&Messias-Reason, I. J. (2021). In vitro study after exposure to the aqueous extract of Piper amalago L. shows changes of morphology, proliferation, cytoskeleton and molecules of the extracellular matrix. Research, Society and Development, 10(4), e0110413289, doi:10.33448/rsd-v10i4.13289.

Shen, J. F., Sugawara, A., Yamashita, J., Ogura, H., \& Sato, S. (2011). Dedifferentiated fat cells: an alternative source of adult multipotent cells from the adipose tissues. Int J Oral Sci. ;3(3):117-124. doi:10.4248/JOS11044. 
Trubiani, O., Scarano, A., \& Orsini, G., et al. (2007). The performance of human periodontal ligament mesenchymal stem cells on xenogenic biomaterials. Int J ImmunopatholPharmacol. 20(1 Suppl 1):87-91. doi:10.1177/039463200702001s1711.

Vasilyev, A. V., Zorina, O. A., Magomedov, R. N., Bukharova, T. B., Fatkhudinova, N. L., Osidak, E. O., Domogatsky, S. P., Goldstein, D. V. (2018). Razlichiia tsitosovmestimosti kostno-plasticheskikh materialov iz ksenogennogo gidroksiapatita s mul'tipotentnymi mezenkhimal'nymi stromal'nymi kletkami, poluchennymi iz pul'py vypavshikh molochnykh zubov i podkozhnogo lipoaspirata [Differences in the cytocompatibility of bone-plastic materials from xenogeneic hydroxyapatite with stem cells from human exfoliated deciduous teeth and adipose tissue-derived mesenchymal stem cells]. Stomatologiia (Mosk). 97(3):7-13. Russian. doi: 10.17116/stomat20189737.

Wang, B., Guo, Y., \& Chen, X., et al. (2018). Nanoparticle-modified chitosan-agarose-gelatin scaffold for sustained release of SDF-1 and BMP-2. Int J Nanomedicine. 13:7395-7408. Published 2018 Nov 12. doi:10.2147/IJN.S180859.

Wolf, M. T., Vodovotz, Y., Tottey, S., Brown, B. N., \& Badylak, S. F. (2015). Predicting in vivo responses to biomaterials via combined in vitro and in silico analysis. Tissue Eng Part C Methods. 21(2):148-159. doi:10.1089/ten.TEC.2014.0167.

Zeitlin, B. D. (2020). Banking on teeth - Stem cells and the dental office. Biomed J. 43(2):124-133. doi: 10.1016/j.bj.2020.02.003.

Zimmermann, A., Pelegrine, A. A., Peruzzo, D., et al. (2015). Adipose mesenchymal stem cells associated with xenograft in a guided bone regeneration model: a histomorphometric study in rabbit calvaria. Int J Oral Maxillofac Implants. 30(6):1415-1422. doi:10.11607/jomi.4164.

Zimmermann, G., \& Moghaddam, A. (2011). Allograft bone matrix versus synthetic bone graft substitutes. Injury. 42 Suppl 2:S16-S21. doi:10.1016/j.injury.2011.06.199. 